\title{
Introduction: African Science Fiction
}

\author{
Moradewun Adejunmobi \\ University of California, Davis
}

As recently as 2009, the Nigerian-American writer, Nnedi Okorafor could ask in a blogpost, "Is Africa ready for science fiction?" She followed this up in 2014 with an equally provocative statement: "African science fiction is still alien." 2 Neither the question nor the statement represented her own convictions; instead they were intended as conceits to instigate conversation about a larger concern, namely, the place of science fiction in African literature and cinema. This special issue of the Cambridge Journal of Postcolonial Literary Inquiry (PLI) on African science fiction extends that conversation with studies of the work of Okorafor herself, but also that of Lauren Beukes, Kojo Laing, Frances Bodomo, and Deji Bryce Olukotun, among others.

Some of the works that will be discussed in this special issue are clearly science fiction, but with other texts, the links are more tenuous. The goal here is not so much to prove that all the creative works under consideration are science fiction, but to determine how African authors use sf (science fiction) elements to interrogate the sociopolitical arrangements that inform the African condition in the current age. As Istvan Csicsery-Ronay Jr., a leading theorist of science fiction, recently conceded in speaking about global science fiction, "Sf will be less a kind of text and more a specific attitude..." In agreement with Istvan Csicsery-Ronay Jr., we are probably on a stronger footing inquiring for sf conventions and sf tropes in African literature and cinema, than searching mainly for generic conformity. Some preliminary and extremely useful work has already been done to begin laying out the terrain for African science fiction studies. Thus, and for an introduction to scholarship on African science fiction, one might look to a number of publications within the past few years. ${ }^{4}$

1 See http://nnedi.blogspot.com/2009/08/is-africa-ready-for-science-fiction.html, Accessed August 20, 2016.

2 See http://nnedi.blogspot.com/2014/01/african-science-fiction-is-still-alien.html, Accessed August 20, 2016

3 Istvan Csicsery-Ronay Jr., "What Do We Mean When We Say 'Global Science Fiction'? Reflections on a New Nexus," Science Fiction Studies 39.3 (2012), 481.

4 For earlier publications on African science fiction, see Mark Bould, "African Science Fiction 101," SFRA Review 311 Winter (2015), 11-18. Bould offers a comprehensive overview of works by Africans that can be read from a science fiction perspective, although the author himself concedes that he is "neither an Africanist, nor an expert on African literatures and cultures" (11). Bould also edited a special issue of the journal Paradoxa, dedicated to African science fiction in 2014: Mark Bould, "Africa SF: Introduction," Paradoxa, 25 (2014), 7-15. One of the earliest articles published on African science fiction is Deidre Byrne's 2004 article in PMLA: Deirdre C. Byrne, "Science Fiction in South Africa," PMLA 119.3 (2004), 522-525. A special edition of the journal, African Identities (7.2), in 2009 was titled "The genre of science fiction and the black imagination"; however, only one of the papers in that special issue focused on African science fiction, namely Taiwo Osinubi's "Cognition's Warp: African Films on Near-future Risk" (255-274). Other articles in the special edition of African Identities looked to African American and African diasporic literature to make the connection between the black imagination and science fiction. 
How then do we read African fiction in the early twenty-first century as science fiction? Within the field of science fiction studies, interest in postcolonial science fiction has been growing for some time and provides suggestive pathways for reading African science fiction. ${ }^{5}$ At least some of this interest stems from a recognition of the extent to which the cultural politics of empire helped to incubate the genre of science fiction. John Rieder notes, for example, that the rising thirst for exploration of alien worlds in fiction starting in the nineteenth century, cannot be detached from growing awareness of an impending disappearance of a certain kind of exploration. He remarks:

If the Victorian vogue for adventure fiction in general seems to ride the rising tide of imperial expansion, particularly into Africa and the Pacific, the increasing popularity of journeys into outer space or under the ground in the late nineteenth and early twentieth centuries probably reflects the near exhaustion of the actual unexplored areas of the globe.... Having no place on Earth left for the radical exoticism of unexplored territory, the writers invent places elsewhere. ${ }^{6}$

This is not to say that science fiction, historically, or in the present has always been complicit with the interests of empire. ${ }^{7}$ Nonetheless, the crosscurrents flowing between representations of alien encounters and the politics of colonialism remain an enduring subject of interest for scholars as evidenced by the many articles examining the films, District 9 and Avatar, as allegories of colonial encounters. Indeed, Neill Blomkamp's District 9 is arguably the work that first revealed the extent to which it was possible to bring together science fiction and the problematic of postcoloniality for those scholars of African literature and cinema who had not previously given any thought to science fiction as a viable genre for African writers or filmmakers. ${ }^{8}$ Since then, scholarly discussions of District 9 have proliferated, but not necessarily in tandem with references to the wider context for African science fiction. ${ }^{9}$ Gradually though, a small number of critics did begin to discern sf traits in other African

5 See for example, Jessica Langer, Science Fiction and Postcolonialism (New York: Palgrave Macmillan, 2011); Masood Ashraf Raja, Jason W. Ellis, and Swaralipi Nandi, eds. The Postnational Fantasy: Essays on Postcolonialism, Cosmopolitics and Science Fiction (Jefferson, NC: McFarland, 2011); and Eric Smith, Globalization, Utopia, and Postcolonial Science Fiction: New Maps of Hope (New York: Palgrave Macmillan, 2012).

6 John Reider, Colonialism and the Emergence of Science Fiction (Middletown, CT: Wesleyan University Press, 2008), 3-4.

7 In the words of Istvan Csicsery-Ronay Jr.: "To say that sf is a genre of empire does not mean that sf artists seek to serve the empire. Most serious writers of sf are skeptical of entrenched power, sometimes because of its tyranny, sometimes because it hobbles technological innovation." "Science Fiction and Empire," Science Fiction Studies 30.2 (2003), 241.

8 Earlier forays into science fiction by filmmakers Jean-Pierre Bekolo and Sylvestre Amoussou were often read as somewhat solitary experiments by these filmmakers, rather than as pointers to a significant new turn in African literary and filmic production.

9 See for example, Michael Valdez Moses, Lucy Valery Graham, John Marx, Gerald Gaylard, Ralph Goodman, and Stefan Helgesson, "District 9: A Roundtable," Safundi: A Journal of South African and American Studies 11.1/2 (2010), 155-175; John Rieder, "Race and Revenge Fantasies in Avatar, District 9, and Inglorious Basterds," Science Fiction Film and Television 4.1 (2011), 41-56; Lorenzo Veracini, "District 9 and Avatar: Science Fiction and Settler Colonialism," Journal of Intercultural Studies 32.4 (2011), 355-367. 
literature and cinema texts that were already in circulation well before the 2009 release of District 9. ${ }^{10}$

With the benefit of hindsight, it is surprising that a science fiction framework for reading African literature did not surface much earlier. One need look no further than some definitions of science fiction to understand why the building blocks of this genre might prove attractive to African artists pondering the unfinished project of postcolonial liberation. In one of his early essays, for example, Darko Suvin defines science fiction as a literary genre "whose main formal device is an imaginative framework alternative to the author's empirical environment." 11 The familiar sf tropes of alien encounters, speculative technologies, utopias and dystopias obviously serve to instantiate this particular device. Istvan Csicsery-Ronay Jr. elaborates further on the idea of an alternative to the empirical environment when he describes science fiction as attending to the "gap that lies between the conceivability of future transformations and the possibility of their actualization," about the relationship between imaginary conceptions and historical reality unfolding into the future." 13 The notion of novum, or "a strange newness" is central to Suvin's conceptualization of science fiction. ${ }^{14}$ In later writings, Suvin specified additionally that the novum "entails a change of the whole universe of the tale, or at least of crucially important aspects thereof." ${ }^{\prime 15}$ Even outside the formal scope of science fiction studies, these particular sf-identified features noted by Suvin and Csicsery-Ronay Jr. are extremely relevant to certain strands of African literature and cinema. How else, for example, could one possibly read Abdourahman Waberi's In the United States of Africa, except as an illustration of that gap between "between the conceivability of future transformations and the possibility of their actualization"? ${ }^{16}$

If, furthermore, the "cognitive estrangement" that Suvin also discerns in science fiction was already a feature of African magical realist and fantasy narratives, ${ }^{17}$ ranging from D.O. Fagunwa's Forest of a Thousand Daemons to Amos Tutuola's The Palm-Wine Drinkard and Ben Okri's The Famished Road, it becomes increasingly clear how long African literature has been on the cusp of science fiction. Although the speculative worlds created by authors like Fagunwa, Tutuola, and Okri are clearly indebted to indigenous myth and folklore, these speculative worlds are not depicted as incompatible with the technologies of modernity such as telephones, televisions, bombs, and cameras, among others. Occasionally too, the technologies themselves are speculative as in Tutuola's well-known figure of the television-handed ghostess. The decision to include any kind of technoscience in these fantasy worlds is itself noteworthy, and is a subject awaiting further study, especially in relation to the practice of speculation and the function of magical resources in the same narratives. That the

10 For example, several of the articles in the special issue of Paradoxa on African science fiction examine works published before the 2009 release of the film District 9.

11 Darko Suvin, "On the Poetics of the Science Fiction Genre," College English 34.3 (1972), 375.

12 Istvan Csicsery-Ronay Jr., "The SF of Theory: Baudrillard and Haraway," Science Fiction Studies 18.1

(1991), 387.

13 Ibid, 388.

14 Suvin, "Poetics," 373.

15 Darko Suvin, Metamorphoses of Science Fiction (New Haven, CT: Yale UP, 1979), 64.

16 Csicsery-Ronay Jr., “Theory," 387.

17 Suvin, "Poetics," 372. 
possible parallels and areas of coincidence between African magical realism and African science fiction, have been frequently overlooked until recently, can be attributed to the fact, observed by Ken Gelder, speaking about the genre of horror, that scholars of postcoloniality have often been more interested in high-brow rather than low brow and popular fictions. ${ }^{18}$ Thus, for example, the spectrality of African magical realist fictions from Okri to Kojo Laing has been a more attractive subject than the science fiction dimensions of work by the same authors in African literary studies.

There are of course significant areas of probable divergence between sf and the problematic of postcolonial liberation as imagined by African writers and filmmakers. To start with, the power and promise of technoscience are rarely realized in the African postcolony. But this might be the reason why for a growing number of African authors, representations of functioning technologies belong more so in the realm of speculative fictions than in realist works, whether such fictions address the future, or adopt a backwards glance, seeking to create what Magalí Armillas-Tiseyra, one of the contributors to this special issue, calls a "speculative history." ${ }^{19}$ More problematically for African science fiction, the enforcement of a strict separation between works incorporating supernatural or magical elements and those works exploring the outcomes of speculative technologies has a long history in sf studies. No less a scholar of sf than Csicsery-Ronay Jr. has confessed that for a long time, he "resisted expanding the term sf to cover writing that does not exclude 'supernatural' motivations." ${ }^{20}$ And while in the same article, he was willing to admit the emergence of a global sf blending the "folkloric, mythological, supernatural" with technoscience, ${ }^{21}$ scholars in African cultural studies are likely to protest when he also diagnoses the mixing of "cyber-skills with witchcraft" among the Sakawa Boys of Ghana as evidence of a premodernist sensibility. ${ }^{22}$ To the contrary, it is precisely modernity and futurity that are at stake in these combinations. As Jean and John Comaroff have aptly put it with respect to the functions of beliefs in magical powers in a neoliberal South Africa, this actually amounts to "a retooling of culturally familiar technologies as new means for new ends." ${ }^{23}$ Three of the five contributors to this special issue (Hugh Charles O'Connell, Ian MacDonald, and Brady Smith) write about works where supernatural abilities associated with indigenous spirituality interface with technoscience. And, Ian MacDonald goes so far as to bestow an original term on this coupling: "jujutech" which might apply to many other works of African science fiction and fantasy. ${ }^{24}$

The proposal for this special issue on African science fiction grew out of a panel titled "African Sci-Fi and Horror" organized at the annual convention of the Modern

18 See Ken Gelder, “Introduction: Global/Postcolonial Horror,” Postcolonial Studies 3.1 (2000), 35.

19 Magalí Armillas-Tiseyra, "Afronauts: On Science Fiction and the Crisis of Possibility," Cambridge Journal of Postcolonial Literary Inquiry 3.3 (2016).

20 Csicsery-Ronay Jr., "Global Science Fiction," 480.

21 Ibid, 481.

22 Ibid, 482. For more on the Sakawa phenomenon, see Alice Armstrong, "'Sakawa' Rumors: Occult Internet Fraud and Ghanaian Identity," Working Paper No. 08/2011, UCL Anthropology Working Papers Series (2011).

23 Comaroff, "Occult Economies and the Violence of Abstraction: Notes from the South African Postcolony," American Ethnologist 26.2 (1999), 284.

24 Ian P. MacDonald, "Let Us All Mutate Together': Cracking the Code in Laing's Big Bishop Roko and the Altar Gangsters," Cambridge Journal of Postcolonial Literary Inquiry 3.3 (2016). 
Language Association of America in 2015. The five contributors to this sf cluster read selected works of African literature as science fiction, or for science fiction, but they also enter into dialogue with multiple strands of theorizing on science fiction in the writings of Donna Haraway, Darko Suvin, Istvan Csicsery-Ronay Jr., Kodwo Eshun, and Fredric Jameson among others. At the same time, their contributions exhibit familiarity with questions relevant to a broad spectrum of African literature, extending well beyond African science fiction. In short, these papers represent a further step towards centering science fiction scholarship in African literary studies.

Magalí Armillas-Tiseyra's article in this issue of PLI addresses a nexus of concerns that is usually held as a defining feature of sf, namely technological advancement and the deployment of speculative technologies, in three novels and two visual works. Space exploration is the speculative technology in play in Deji Olukotun's Nigerians in Space, Ngugi wa Thiong'o's Wizard of the Crow, and the two visual works: Cristina de Middel's The Afronauts and Frances Bodomo's Afronauts. While Sony Labou Tansi's Life and a Half focuses on a different kind of technological advance; what it has in common with the other works discussed, is the incongruity of placing projects dependent on advanced technologies in an African setting. The presumed incommensurability between deployment of advanced technology and an African setting is the starting point for Armillas-Tiseyra's discussion of how a novum can be generated in relation to an African context. As she rightly notes, "At stake here are assumptions about "Africa"-as a set of ideas about the continent-and its relationship to technology as well as to "modernity," as defined by the global North." 25 The fact that, a planned voyage to the moon, the "speculative technology" featured in four of the works is in fact no longer speculative in the early twenty-first century is directly relevant to Armillas-Tiseyra's argument about speculation and the novum. All of the works in question were produced decades after the space exploration race of the Cold War. For Armillas-Tiseyra, this rewriting of a real history in which Africa had no place is itself a "utopian gesture" and a way of creating a speculative history.

In her paper, and even more so than Armillas-Tiseyra, Nedine Moonsamy takes up the sf trope of utopia, and in this instance, technologically produced and sterile utopias. Her study of three short stories from the Afro SF: Science Fiction by African Writers Vol I (2012) anthology, ${ }^{26}$ considers how the friction between the emancipatory potential of an imagined utopia and the danger of contagion from known and unknown contaminants comes to stand in for the project of postcolonial liberation in African science fiction. In each of the three stories by Sarah Lotz, Tendai Huchu, and Nick Wood, a techno-scientifically engineered utopia presents human subjects with a choice between mechanistic efficiency, chemically induced euphoria, and the possible decay associated with contamination. For Moonsamy, Lotz's story confirms the conservative and nationalistic turn that Prisicilla Wald has diagnosed in many contagion narratives. ${ }^{27}$ By contrast, and in the stories by Huchu and Wood, the uncertain rewards of contagion outweigh any conjectural hazards, prompting protagonists to

25 Armillas-Tiseyra, "Afronauts."

26 Ivor Hartmann, ed., AfroSF: Science Fiction by African Writers (Johannesburg: Storytime, 2012).

27 Priscilla Wald, Contagious: Cultures, Carriers, and the Outbreak Narrative (Durham and London: Duke University Press, 2008). 
seek escape from the security that technoscientific utopia promises. Nonetheless, Moonsamy finds that in different ways, all three stories problematize the technoscientific and sterile utopia of many sf narratives. For Moonsamy, the selected works of African science fiction, "contaminate the notion of utopia itself" through their questioning of the desire for a world made free from what are perceived to be social pollutants. ${ }^{28}$

In his article, Ian MacDonald undertakes a close reading of a novel that has been described as "sprawling," and "most difficult." ${ }^{\text {"2 }}$ Indeed, future readers of Kojo Laing's Big Bishop Roko will be highly indebted to MacDonald for providing a helpful entry point into this complex narrative. MacDonald's essay approaches Big Bishop Roko as a sequel to an earlier work by Laing, namely, Major Gentl. Both novels explore what is now commonly described as the digital divide. According to MacDonald, Big Bishop Roko presents a reflection on the ethical implications of advances in genetic engineering and cloning for humankind, as well as the possible outcomes of these advances for societies in the Global South. MacDonald's title "Let Us All Mutate Together" alludes to the problem that these advances in scientific practice pose for those who are excluded from access to new technologies, by virtue of their subject locations. In the novel, and as a handful of individuals in the "developing world" begin to mutate into genetically superior and networked cyborgs, the rest of the population is reduced to mere humanity, without connection to the emerging cyber networks. In MacDonald's words, "the Global South becomes the repository for a suddenly antiquated, primitive mode of being: that of being human." ${ }^{30}$ The African protagonist of the novel embraces some mutations from the Global North which are already occurring, but also adopts what MacDonald calls "jujutech," the fusion of indigenous practices and new technologies that also become a means for advancing genetic engineering on the local front. MacDonald interprets Laing's novel as an inquiry into how communities around the world might respond to differential experiences of technological advancement, rather than as a critique of technoscience necessarily, or a plea for the continuing relevance of beliefs in magic. As MacDonald himself acknowledges, the technomagical world revealed in Laing's novel makes for a different kind of science fiction, but science fiction, nonetheless, which engages with questions pertaining to genetic modification and posthumanism that not infrequently attract speculation in global science fiction.

Drawing from scholarship on postcolonial urbanity and ecocriticism, as well as his own interest in "speculative urbanism," Brady Smith's essay examines trends in African speculative fiction, with examples from two novels by Lauren Beukes. Specifically, Smith proposes a preliminary reading of Beukes' Moxyland and Zoo City in relation to theorizing on the Anthropocene. ${ }^{31}$ While both novels clearly ponder the

28 Nedine Moonsamy, "Life is a Biological Risk: Contagion, Contamination and Utopia in African Science Fiction." Cambridge Journal of Postcolonial Literary Inquiry 3.3 (2016).

29 See Bould, "Science Fiction 101," 14.

30 MacDonald, "Let Us All Mutate."

31 In this respect, Brady Smith's article shares somewhat similar concerns in common with Matthew Omelsky's 2014 article on Post-crisis African science fiction also published in PLI, though each author examines a different corpus of texts and approaches the Anthropocene from a different perspective. The Anthropocene/speculative fiction nexus is evidently an area of investigation likely to generate continuing 
question of human agency in an African future experiencing increased coincidence of nature and humanity, this article also establishes why Beukes' writing should be read alongside theorizing on science fiction in addition to ecocriticism. Like several of the papers included in this special issue, Smith zeroes in on future technologies, but which somehow seem to take us back to past spirituality. His argument here is that unlike some sf trends elsewhere in the world, Beukes' depiction of new technologies of social control and the mixing of speculative technology with indigenous spirituality is not about nostalgia or about a desire for return to uncontaminated nature; rather it anticipates a postcolonial future which will always be hybrid in its expression. Furthermore, declares Smith, this notably postcolonial future mirrors the anticipated future of humanity in the age of the Anthropocene. In this future world of hybrid technologies and life forms, ancestral worship migrates to new media technologies, instead of disappearing, and humans become one with both nature and infrastructure. Accordingly, and even when new technologies reign supreme in the imagined future South Africa, the allure of old "technologies" does not wane, nor does reliance on advanced technologies alone suffice to resolve the social tensions inherited from an earlier age.

With Hugh Charles O'Connell's paper, we return to the novum, one of the more prominent concepts elaborated upon in the field of science fiction studies. In his paper, and using theorizing about sf conventions from Afrofuturism as a point of departure, O'Connell argues for reconsidering how distinctive moments operate as nova in African and African Diasporic narratives of speculation. Given the weight of history, recounting alien encounters set in a postcolonial context from the vantage point of a postcolonial subject produces particular challenges. If the novum represents something new that cannot according to O'Connell "be known ahead of time,"32 how then can newness be adduced to second contact encounters with "alien aliens" in narratives that appear to replay the very trajectory of stories about first contact with alien colonizers or alien slave traders or more recently alien philanthropists and saviors? Second contact narratives will yield limited novelty where memories of first contact have not yet dissipated. O'Connell's discussion of this conundrum focuses on Nnedi Okorafor's novel Lagoon which seemingly recounts a typical sf encounter between technologically sophisticated and seemingly benevolent aliens and merely human subjects set in Lagos, Nigeria. To accept the aliens in Lagoon at face value as benevolent agents equipped with technology would be to remove the work from the realm of speculation, and to deprive the narrative of an emancipatory potential. In his reading of Okorafor's novel, O'Connell proposes, instead, that the encounter with aliens be viewed mainly as a placeholder for interrogating that which is not yet known, and cannot yet be imagined. Like Moonsamy in this special issue, who concludes that African speculative imaginations of utopia wear away at the very notion of utopia, O'Connell finds that in African and African Diasporic writing, the critical edge

and considerable interest in African science fiction studies as the field of scholarship expands. Please see Matthew Omelsky, "After the End Times': Postcrisis African Science Fiction," Cambridge Journal of Postcolonial Literary Inquiry, 1.1 (2014), 33-49.

32 Hugh Charles O'Connell, "We are change': The Novum as Event in Nnedi Okorafor's Lagoon," Cambridge Journal of Postcolonial Literary Inquiry 3.3 (2016). 
sometimes associated with sf conventions can best be uncovered when the conventions themselves are made subject to reinterpretation.

Together, these five papers contribute to the scholarship locating African science fiction and African horror in relation to postcoloniality, as well as neoliberalism and globalization. They establish a preliminary framework for explicating African science fiction with respect to other trends in African literature. And finally, they help to advance a basis for mapping the interrelations between African science fiction and related genres from around the world, depicting subjects from communities frequently associated with experiences of marginality, exclusion, and subordination. 